\title{
Colonization of the Arabidopsis rhizosphere by fluorescent Pseudomonas spp. activates a root-specific, ethylene-responsive $P R-5$ gene in the vascular bundle
}

\author{
Karen M. Léon-Kloosterziel ${ }^{1,3, \dagger}$, Bas W.M. Verhagen ${ }^{1,4, \dagger}$, Joost J.B. Keurentjes ${ }^{1,5}$, \\ Johan A. VanPelt ${ }^{1}$, Martijn Rep ${ }^{2}$, L.C. VanLoon ${ }^{1}$ and Corné M.J. Pieterse ${ }^{1, *}$ \\ ${ }^{1}$ Graduate School Experimental Plant Sciences, Section Phytopathology, Faculty of Biology, Utrecht \\ University, P.O. Box 800.84, 3508 TB Utrecht, the Netherlands (*author for correspondence; e-mail \\ C.M.J.Pieterse@bio.uu.nl,http://www.bio.uu.nl/ fytopath); ${ }^{2}$ Plant Pathology, Swammerdam Institute for \\ Life Sciences, Faculty of Science, University of Amsterdam, P.O. Box 94062, 1090 GB Amsterdam, the \\ Netherlands; ${ }^{3}$ present address: Department of Cell Biology and Immunology, Wageningen University, P.O. \\ Box 338, 6700 AH Wageningen, the Netherlands; ${ }^{4}$ present address: Laboratoire dEco-Toxicologie, UFR \\ Science Exactes et Naturelles, Université de Reims, Moulin de la Housse, BP1039 - 51687, Reims, France; \\ 5 present address: Laboratory of Genetics, Wageningen University, Arboretumlaan 4, 6703 BD, Wageningen, \\ the Netherlands; ${ }^{\dagger}$ The authors contributed equally to this work
}

Received 25 October 2004; accepted in revised form 28 February 2005

Key words: defense-related gene expression, enhancer trap, ethylene, ISR, Pseudomonas fluorescens, thaumatin-like protein

\begin{abstract}
Plants of which the roots are colonized by selected strains of non-pathogenic, fluorescent Pseudomonas spp. develop an enhanced defensive capacity against a broad spectrum of foliar pathogens. In Arabidopsis thaliana, this rhizobacteria-induced systemic resistance (ISR) functions independently of salicylic acid but requires responsiveness to jasmonic acid and ethylene. In contrast to pathogen-induced systemic acquired resistance (SAR), ISR is not associated with systemic changes in the expression of genes encoding pathogenesis-related (PR) proteins. To identify genes that are specifically expressed in response to colonization of the roots by ISRinducing Pseudomonas fluorescens WCS417r bacteria, we screened a collection of Arabidopsis enhancer trap and gene trap lines containing a transposable element of the $A c / D s$ system and the $G U S$ reporter gene. We identified an enhancer trap line (WET121) that specifically showed GUS activity in the root vascular bundle upon colonization of the roots by WCS417r. Fluorescent Pseudomonas spp. strains P. fluorescens WCS374r and $P$. putida WCS358r triggered a similar expression pattern, whereas ISR-non-inducing Escherichia coli bacteria did not. Exogenous application of the ethylene precursor 1-aminocyclopropane-1-carboxylate (ACC) mimicked the rhizobacteria-induced GUS expression pattern in the root vascular bundle, whereas methyl jasmonic acid and salicylic acid did not, indicating that the Ds element in WET121 is inserted in the vicinity of an ethylene-responsive gene. Analysis of the expression of the genes in the close vicinity of the $D s$ element revealed $A T T L P 1$ as the gene responsible for the in cis activation of the GUS reporter gene in the root vascular bundle. AtTLPI encodes a thaumatin-like protein that belongs to the PR-5 family of PR proteins, some of which possess antimicrobial properties. AtTLP1 knockout mutant plants showed normal levels of WCS417r-mediated ISR against the bacterial leaf pathogen Pseudomonas syringae pv. tomato DC3000, suggesting that expression of $A t T L P l$ in the roots is not required for systemic expression of ISR in the leaves. Together, these results indicate that induction of AtTLPl is a local response of Arabidopsis roots to colonization by non-pathogenic fluorescent Pseudomonas spp. and is unlikely to play a role in systemic resistance.
\end{abstract}




\section{Introduction}

Selected strains of non-pathogenic, root-colonizing bacteria can stimulate plant growth and are, therefore, referred to as plant growth-promoting rhizobacteria (PGPR) (Kloepper et al., 1980). Plant growth promotion results mainly from suppression of soil-borne pathogens and other deleterious micro-organisms, but also direct effects on plant growth have been reported (Schippers et al., 1987). Fluorescent Pseudomonas spp. are among the most effective suppressors of disease and have been shown to be responsible for the reduction of soil-borne diseases in naturally disease-suppressive soils (Raaijmakers and Weller, 1998). Disease suppressive activity can be the result of competition for nutrients, siderophoremediated competition for iron, antibiosis, or the production of lytic enzymes (Van Loon and Bakker, 2003).

Apart from direct antagonistic effects on soilborne pathogens, some rhizobacterial strains are able to reduce disease in above-ground plant parts through a plant-mediated mechanism that is commonly referred to as induced systemic resistance (ISR) (Van Loon et al., 1998). Rhizobacteriamediated ISR has been demonstrated in many plant species, and is effective against a broad spectrum of plant pathogens, including oomycetes, fungi, bacteria and viruses (Van Loon et al., 1998). Phenotypically, rhizobacteria-mediated ISR resembles classic pathogen-induced resistance, in which noninfected parts of infected plants become more resistant to further infection. This latter form of induced resistance is known as systemic acquired resistance (SAR) (Ross, 1961; Sticher et al., 1997).

Pseudomonas fluorescens strain WCS417r has been shown to trigger ISR in several plant species, e.g. carnation (Van Peer et al., 1991), radish (Leeman et al., 1995), tomato (Duijff et al., 1998), bean (Bigirimana and Höfte, 2002) and Arabidopsis (Pieterse et al., 1996; Pieterse et al., 2002). Colonization of Arabidopsis roots by WCS417r protects the plant systemically against different types of pathogens, including the bacterial leaf pathogens Pseudomonas syringae pv. tomato (Pst) and Xanthomonas campestris pv. armoraciae, the fungal root pathogen Fusarium oxysporum f.sp. raphani, the fungal leaf pathogen Alternaria brassicicola, and the oomycete leaf pathogen Peronospora parasitica (Pieterse et al.,
1996; Van Wees et al., 1997; Ton et al., 2002b). The spectrum of effectiveness of WCS417r-mediated ISR and pathogen-induced SAR overlaps, but is also partly divergent. For instance, ISR is effective against $A$. brassicicola, whereas SAR is not. Conversely, SAR is effective against turnip crinkle virus (TCV), whereas ISR is not (Ton et al., 2002b). In some cases, the level of induced protection can be enhanced further when both ISR and SAR are activated simultaneously (Van Wees et al., 2000), indicating that the effects of both types of induced resistance are additive.

It has been established that the signal transduction pathways of rhizobacteria-mediated ISR and pathogen-induced SAR are distinct. The state of SAR is characterized by an early increase in endogenously synthesized salicylic acid (SA), and the concomitant activation of a set of so-called SAR genes (Sticher et al., 1997). Many SAR genes encode pathogenesis-related (PR) proteins (PRs) (Van Loon and Van Strien, 1999), some of which have been shown to possess anti-fungal activity and are thought to contribute to the induced resistant state. Arabidopsis mutants affected in SA production, and transgenic $\mathrm{NahG}$ plants that express the bacterial salicylate hydroxylase $(n a h G)$ gene, are incapable of developing SAR and do not show SAR gene activation upon pathogen infection, indicating that $\mathrm{SA}$ is a necessary intermediate in the SAR signaling pathway (Gaffney et al., 1993; Wildermuth et al., 2001; Nawrath et al., 2002). Transduction of the SA signal requires the function of the regulatory protein NPR1 (Dong, 2004; Pieterse and Van Loon, 2004). Interaction of NPR1 with b-ZIP TGA transcription factors is required for activation of the SA-regulated $P R$-genes, suggesting that NPR1 acts by altering the activity of transcription factors (Dong, 2004).

Some rhizobacteria trigger the SA-dependent SAR pathway by producing SA on the root (De Meyer et al., 1999; Maurhofer et al., 1998). However, WCS417r induces normal levels of protection against Pst strain DC3000 in Arabidopsis genotypes that are impaired in SA accumulation (i.e. NahG, eds5-1, sid2-1) (Pieterse et al., 1996; Pieterse et al., 2002; Ton et al., 2002a). Moreover, WCS417r-mediated ISR in wild-type Arabidopsis plants is not accompanied by activation of the SAR marker genes $P R-1, P R-2$, and $P R-5$ (Pieterse et al., 1996; Van Wees et al., 1997). 
Thus, this type of induced resistance functions independently of SA. Analysis of the jasmonic acid (JA)-response mutant jar 1-1, a range of ethylene (ET)-response mutants, and the SAR-compromised mutant nprl-1 revealed that components of the JA- and the ET-response are required for triggering WCS417r-mediated ISR, but that like SAR, this induced resistance response depends on NPR1 (Knoester et al., 1999; Pieterse et al., 1998). However, downstream of NPR1, the ISR and the SAR signaling pathways diverge, because unlike SAR, ISR is not accompanied by the concomitant activation of $P R$ genes (Pieterse et al., 1996; Van Wees et al., 1999; Van Wees et al., 1997). Apart from WCS417r, other fluorescent Pseudomonas spp. strains have also been shown to induce SAindependent ISR in Arabidopsis (Van Wees et al., 1997; Iavicoli et al., 2003; Ryu et al., 2003), tobacco (Press et al., 1997; Zhang et al., 2002) and tomato (Yan et al., 2002), indicating that the ability to trigger an SA-independent pathway controlling systemic resistance is not uncommon among ISR-inducing rhizobacteria.

In Arabidopsis, both JA and ET activate specific sets of defense-related genes (Schenk et al., 2000) and, when applied exogenously, each of both can induce resistance (Pieterse et al., 1998; Van Wees et al., 1999). To investigate whether ISR is associated with changes in JA/ET-responsive gene expression, Van Wees et al. (1999) monitored the expression of a set of well-characterized JAand/or ET-responsive genes (i.e. $L O X 1, L O X 2$, $V S P 2, P D F 1.2, H E L, C H I-B$, and $P A L 1)$ in Arabidopsis plants expressing WCS417r-mediated ISR. None of these genes was up-regulated in induced plants, neither locally in the roots, nor systemically in the leaves. This suggested that the resistance attained was not associated with major increases in the levels of either JA or ET. Indeed, analysis of JA and ET levels in leaves of ISRexpressing plants revealed no changes in the production of these signal molecules (Pieterse et al., 2000; Hase et al., 2003). Therefore, it had to be assumed that the JA and ET dependency of ISR is based on an enhanced sensitivity to these hormones, rather than on an increase in their production.

To identify ISR-related genes, we recently surveyed the transcriptional response of over 8,000 Arabidopsis genes during rhizobacteria-mediated ISR (Verhagen et al., 2004). However, systemically in the leaves, none of the $\sim 8000$ genes tested showed a consistent change in expression in response to effective colonization of the roots by WCS417r, indicating that the onset of ISR in the leaves is not associated with detectable changes in gene expression. After challenge inoculation of WCS417r-induced plants with the bacterial leaf pathogen Pst DC3000, 81 genes showed an augmented expression pattern in ISR-expressing leaves compared to inoculated control leaves, suggesting that ISR-expressing plants are primed to respond faster and/or more strongly upon pathogen attack. The majority of the identified potentiated genes was predicted to be regulated by JA and/or ET signaling. Priming is a process that provides the plant with an enhanced capacity for rapid and effective activation of cellular defense responses that are induced only after contact with a pathogen (Conrath et al., 2002). It allows the plant to react more effectively to the invader encountered, which might explain the broad-spectrum action of induced resistance.

In a complementary approach to identify novel defense-related genes that are potentially involved in rhizobacteria-mediated ISR, we screened a collection of gene trap and enhancer trap lines with transposable elements of the $A c / D s$ system carrying the $\beta$-glucuronidase (GUS) reporter gene (Sundaresan et al., 1995; Vroemen et al., 1998), for genes that are specifically expressed in response to colonization of the roots by ISR-inducing WCS417r bacteria. Here, we identified a thaumatin-like gene $(A t T L P I)$ that is specifically expressed in the root vascular bundle after colonization by fluorescent Pseudomonas spp., and after treatment with the ET precursor 1-aminocyclopropane-1-carboxylate (ACC). The putative thaumatin-like protein shows high homology to members of the PR-5 group of PR proteins.

\section{Materials and methods}

\section{Bacterial and fungal cultures}

Non-pathogenic, rifampicin-resistant Pseudomonas fluorescens strain WCS417r was used for induction of ISR and for screening the enhancer trap and gene trap collection. WCS417 $r$ was grown for $24 \mathrm{~h}$ at $28{ }^{\circ} \mathrm{C}$ on Kings medium B agar plates (King et al., 1954) containing the appropriate 
antibiotics as described previously (Pieterse et al., 1996). Subsequently, bacteria were collected and resuspended in $10 \mathrm{mM} \mathrm{MgSO}_{4}$ to a density of $10^{9} \mathrm{cfu} \mathrm{ml} \mathrm{ml}^{-1}\left(\mathrm{OD}_{660}=1.0\right)$ before being mixed through the soil. Growth of Pseudomonas fluorescens strain WCS374r, Pseudomonas putida strain WCS358r, and Escherichia coli strain S17 for analysis of GUS expression in WET121 was performed in a similar manner.

An avirulent strain of $P$. syringae pv. tomato DC3000 carrying the avirulence gene avrRpt2 (Pst DC3000(avrRpt2)) (Kunkel et al., 1993) was used for induction of SAR. Pst DC3000(avrRpt2) bacteria were grown overnight at $28{ }^{\circ} \mathrm{C}$ in liquid $\mathrm{KB}$ supplemented with $25 \mathrm{mg} \mathrm{ml}^{-1}$ kanamycin to select for the plasmid. After centrifugation, the bacterial cells were resuspended in $10 \mathrm{mM} \mathrm{MgSO}_{4}$ to a final density of $10^{7} \mathrm{cfu} \mathrm{m}{ }^{-1}$. Virulent Pst DC3000 (Whalen et al., 1991), used for challenge inoculations, was cultivated in a similar manner in liquid $\mathrm{KB}$ without kanamycin. After centrifugation, the bacterial cells were resuspended in $10 \mathrm{mM} \mathrm{MgSO}_{4}, 0.015 \%$ (v/v) Silwet L-77 (Van Meeuwen Chemicals, Weesp, the Netherlands) to a final density of $2.5 \times 10^{7} \mathrm{cfu} \mathrm{m}^{-1}$.

\section{Plant growth conditions}

For induction of ISR or isolation of RNA or DNA from leaves, seeds of wild-type Arabidopsis thaliana accessions Landsberg erecta (Ler-0), enhancer trap line WET121, starter lines $A c 2$ and DsE3 (Vroemen et al., 1998), and AtTLPI knockout mutant line SGT5141 (Parinov et al., 1999) were sown in quartz sand. WET121, SGT5141, $A c 2$ and $D s E 3$ lines were in the Ler-0 background. Two-week-old seedlings were transplanted into 60$\mathrm{ml}$ pots containing a sand/potting soil mixture $(5: 12, \mathrm{v} / \mathrm{v})$ that had been autoclaved twice for 20 min with a 24-h interval. Prior to transfer of the Arabidopsis seedlings, a suspension of ISR-inducing WCS417r bacteria $\left(10^{9} \mathrm{cfu} \mathrm{ml}^{-1}\right)$ was mixed thoroughly through the soil to a final density of $5 \times 10^{7} \mathrm{cfu}^{-1}$ as described previously (Pieterse et al., 1996). Control soil was supplemented with an equal volume of $10 \mathrm{mM} \mathrm{MgSO}$.

For isolation of RNA from roots, 2-week-old seedlings were laid out horizontally on rock-wool cubes (Rock-wool/Grodan B.V., Roermond, the Netherlands) as described previously (Pieterse et al., 1996; Van Wees et al., 1997). Subsequently, the root systems were covered with $1 \mathrm{ml}$ of a 1:1 $(\mathrm{w} / \mathrm{v})$ mixture of talcum powder and either a suspension of ISR-inducing WCS417r in $10 \mathrm{mM}$ $\mathrm{MgSO}_{4}$ (final density $5 \times 10^{8} \mathrm{cfu} \mathrm{g}^{-1}$ ), or a solution of $10 \mathrm{mM} \mathrm{MgSO}_{4}$ as a control. Plants were cultivated in a growth chamber with a 9-h day $\left(200 \mu \mathrm{E} \mathrm{m}^{-2} \mathrm{~s}^{-1}\right.$ at $\left.24{ }^{\circ} \mathrm{C}\right)$ and a 15 -h night $\left(20{ }^{\circ} \mathrm{C}\right)$ cycle at $70 \%$ relative humidity.

Plants received a modified half-strength Hoagland nutrient solution $\left(2 \mathrm{mM} \mathrm{KNO}_{3}, 5 \mathrm{mM}\right.$ $\mathrm{Ca}\left(\mathrm{NO}_{3}\right)_{2}, 1 \mathrm{mM} \mathrm{KH_{2 }} \mathrm{PO}_{4}, 1 \mathrm{mM} \mathrm{MgSO}$, and trace elements, pH 7 (Hoagland and Arnon, 1938)) once a week as described previously (Pieterse et al., 1996).

\section{Bioassays}

Induction of ISR was performed by mixing ISRinducing WCS417r bacteria through the soil as described above. Induction of SAR was performed 3 days before challenge inoculation by pressure infiltrating three lower leaves with a suspension of avirulent $P$ st $\mathrm{DC} 3000$ (avrRpt2) bacteria at $10^{7} \mathrm{cfu}$ $\mathrm{ml}^{-1}$ as described previously (Pieterse et al., 1996). For assaying induced resistance, plants were challenged when 5 weeks old by dipping the leaves for $2 \mathrm{~s}$ in a suspension of virulent Pst DC3000 bacteria at $2.5 \times 10^{7} \mathrm{cfu}^{-1} \mathrm{ml}^{-1}$ in $10 \mathrm{mM} \mathrm{MgSO}$, $0.015 \%(\mathrm{v} / \mathrm{v})$ Silwet L-77. One day before challenge inoculation, the plants were placed at $100 \%$ relative humidity. Four days after challenge, disease severity was assessed by determining the percentage of diseased leaves per plant. Leaves were scored as diseased when showing necrotic or water-soaked lesions surrounded by chlorosis. From the number of diseased and non-diseased leaves, the disease index was calculated for each plant $(n=20)$. Colonization levels of the rhizosphere of the tested plants by rifampicin-resistant WCS417r bacteria were determined at the end of ISR bioassays as described (Pieterse et al., 1996). In all cases, the number of colony-forming units per gram of root fresh weight ranged between $10^{6}$ and $10^{7}$ (data not shown), which is well above the threshold level required for induction of ISR (Van Loon et al., 1998).

\section{Gene trap and enhancer trap screening}

For the Arabidopsis gene trap and enhancer trap screening, a collection of 200 Wageningen Gene 
Trap (WGT) lines and 400 Wageningen Enhancer Trap (WET) lines (in Ler-0 background) was used that was kindly provided by Dr C.W. Vroemen (Wageningen University, The Netherlands). Construction of the gene trap and enhancer trap lines (Vroemen et al., 1998) was based on transposable elements of the $A c / D s$ system carrying the GUS reporter gene (Sundaresan et al., 1995). For the selection procedure, seeds were surface sterilized with $2 \%(\mathrm{w} / \mathrm{v})$ sodium hypochlorite in $50 \%(\mathrm{v} / \mathrm{v})$ ethanol and sown on $0.6 \%(\mathrm{w} / \mathrm{v})$ agar plates containing $0.46 \%(\mathrm{w} / \mathrm{v})$ Murashige and Skoog (MS) salts (Duchefa BV, Haarlem, the Netherlands), $1.0 \%(\mathrm{w} / \mathrm{v})$ sucrose and $50 \mathrm{mg}^{-1}$ kanamycin to select for plants with the gene/enhancer trap construct among the heterozygous lines. The plates were incubated in a growth cabinet with an 9-h day $\left(24{ }^{\circ} \mathrm{C}\right)$ and 15 -h night $\left(20^{\circ} \mathrm{C}\right)$ cycle. After 11-12 days, the seedlings were transferred to soil with or without ISR-inducing WCS417r bacteria as described above. Four and eleven days after transfer to soil, whole seedlings were removed from the soil, rinsed with tap water to remove excess soil particles from the roots, and analyzed for GUS expression.

For histochemical localization of GUS activity, whole plants were immersed in GUS staining solution containing $1 \mathrm{mM}$ X-Gluc (5-bromo4-chloro-3-indolyl B-D-glucuronide) in $100 \mathrm{mM}$ $\mathrm{NaP}_{\mathrm{i}}$ buffer $\mathrm{pH}$ 7.0, $10 \mathrm{mM}$ EDTA, $0.1 \%$ Triton $\mathrm{X}-100$ as described (Spoel et al., 2003). After overnight incubation at $37^{\circ} \mathrm{C}$, the plants were destained by repeated washes in $70 \%$ ethanol and inspected under a stereomicroscope. For differential interference contrast microscopy, the GUS staining solution was complemented with $0.5 \mathrm{mM}$ potassium ferricyanide and $0.5 \mathrm{mM}$ potassium ferrocyanide, and the plants were incubated at $37^{\circ} \mathrm{C}$ for 3 days. After destaining, the plants were cleared by incubation in clearing solution $(7 \mathrm{~g}$ chloralhydrate, $1 \mathrm{ml}$ glycerol, $2 \mathrm{ml}$ water) for $2-$ $16 \mathrm{~h}$.

\section{GUS expression in WET121}

Homozygous WET121 seeds were surface sterilized and sown on MS-agar plates supplemented with $0.1 \mathrm{mM}$ SA, $0.01 \mathrm{mM}$ MeJA, or $0.1 \mathrm{mM}$ ACC as described (Spoel et al., 2003; Ton et al., 2002a). Plants were grown for 14 days prior to determination of GUS activity. Because ACC inhibits growth, alternatively, seeds were sown on MS-agar plates as described above and after 12 days $2 \mathrm{ml}$ of a solution containing $1 \mathrm{mM}$ ACC was added. GUS expression was determined 6 days after ACC application. MeJA was purchased from Serva Brunschwig (Amsterdam, the Netherlands), ACC from Sigma-Aldrich Chemie BV (Zwijndrecht, the Netherlands) and SA from Mallinckrodt Baker BV (Deventer, the Netherlands).

To determine the effect of bacterial treatments, seeds were sown on $0.7 \%$-agar plates containing half-strength Hoagland nutrients and $10 \mu \mathrm{M}$ Sequestreen (Ciba Geigy, Basel, Switzerland). The agar plates were incubated vertically to allow development of the root system along the surface of the agar plates. After 14 days, $1 \mu \mathrm{l}$ of a bacterial suspension containing $10^{7} \mathrm{cfu} \mathrm{ml}{ }^{-1}$ of WCS417r was applied at the base of the hypocotyl, resulting in colonization of the whole root system within $24 \mathrm{~h}$. Four days later, GUS expression was determined as described above. Analysis of GUS expression in response to treatment of the roots with P. fluorescens WCS374r, P. putida WCS358r, or E. coli strain $\mathrm{S} 17$ was performed in a similar manner.

Analysis of flanking sequences of the Ds insertion in WET121

Isolation of genomic DNA and Southern blot analysis were performed as described previously (Vroemen et al., 1998). To amplify genomic sequences flanking the $D s$ insertion in WET121, TAIL-PCR was performed essentially as described (Liu et al., 1995; Vroemen et al., 1998). In brief, two arbitrary degenerate (AD) primers, and three specific nested $D s$ primers were used to amplify the $D s$ flanking sequences in a primary, a secondary and a tertiary round of TAIL-PCR. In the consecutive rounds of TAIL-PCR, the positions of the $D s$ primers were chosen closer to the $5^{\prime}$-end of the $D s$ element. This resulted in consecutively smaller PCR products, indicative of a successful amplification of flanking sequences. Primers used were the nested specific primers located on the $5^{\prime}$ end of the $D s$ element: Ds5-1, $5^{\prime}$-CCG TTT ACC GTT TTG TAT ATC CCG-3'; Ds5-2, 5'-CGT TCC GTT TTC GTT TTT TAC C-3'; Ds5-3, 5'GGT CGG TAC GGA ATT CTC CC-3'; and the arbitrary degenerate (AD) primers $\mathrm{AD}-2,5^{\prime}$-NGT 
CGA $(\mathrm{C} / \mathrm{G})(\mathrm{A} / \mathrm{T}) \mathrm{G}$ ANA (A/T)GA A-3', AD-3, $5^{\prime}$-(A/T)GT GNA G(A/T)A NCA NAG A-3'. The products from the tertiary PCR reaction were separated on an agarose gel, isolated from the gel, cloned into pGEM-T-easy vector (Promega), and sequenced using universal T7 and SP6 sequencing primers.

\section{Alignment software and phylogenetic tree construction}

Alignment of amino acid sequences was performed using MegAlign software (DNAStar). Phylogenetic tree construction was done with MacVector (Oxford Molecular Group) as described previously (Rep et al., 2002).

\section{Northern blot analysis and RT-PCR}

Total RNA was extracted by homogenizing frozen tissue in extraction buffer $(0.35 \mathrm{M}$ glycine, $0.048 \mathrm{M} \mathrm{NaOH}, 0.34 \mathrm{M} \mathrm{NaCl}, 0.04 \mathrm{M}$ EDTA, $4 \%(\mathrm{w} / \mathrm{v}) \mathrm{SDS} ; 1 \mathrm{ml}$ per $\mathrm{g}$ plant tissue). The homogenates were extracted with phenol/chloroform/isoamylalcohol $(25: 24: 1 ; \mathrm{v} / \mathrm{v} / \mathrm{v})$ and the RNA was precipitated using $\mathrm{LiCl}$, as described (Sambrook et al., 1989). Analysis of gene expression in the roots was performed by RT-PCR as described earlier (Pieterse et al., 1998). Analysis of gene expression in the leaves was performed by northern blot analysis. To this end, $15 \mu \mathrm{g}$ of RNA was denatured using glyoxal and DMSO as described (Sambrook et al., 1989). Subsequently, samples were electrophoretically separated on $1.5 \%$ agarose gels and blotted onto Hybond- $\mathrm{N}^{+}$ membranes (Amersham, s-Hertogenbosch, the Netherlands) by capillary transfer. Northern blots were hybridized with gene-specific probes as described previously (Pieterse et al., 1998). Templates for the preparation of gene-specific probes were prepared by PCR with the primers described below. After hybridization with $\alpha-{ }^{32} \mathrm{P}$-dCTPlabelled probes, blots were subjected to autoradiography and signals quantified using a BioRad Molecular Imager FX (BioRad, Veenendaal, the Netherlands) with Quantity One software (BioRad, Veenendaal, the Netherlands).

For detection of the AtTLP1 transcript, the following gene-specific primers were designed based on the annotated sequences corresponding to AGI number At4g24180: AtTLP1-FOR
5'-AGC ATT GCA TTT GGT AGG AAG TGA-3', AtTLP1-REV 5'-CTA GGC AAG GAA GGG CAA AAA GT-3'. Detection of KHCLP, SHEPHERD, and TUB gene expression was performed in a similar manner with primers based on the annotated sequences corresponding to AGI numbers At4g24170 (KHCLP), At4g24190 (SHEPHERD) and At5g44340 (TUB): SHEPHERD-FOR, 5'-CTG ATG GAT TAC GAA GAC AAA AAG-3'; SHEPHERD-REV, 5'-GTA AAC ACA AAG GAG AAA CAT CAG-3'; KHCLP-FOR, 5'-CTA AAA GCC TAA GTG GAG TGC-3'; KHCLP-REV, 5'-GCG GAG AAG AGA AGA TAT TGG-3' and TUB-FOR 5'-AAT ACG TCG GCG ATT CTC CG-3'; TUBREV, 5'-CAC AGA CAC TGG ACT TGA CG-3'. For RT-PCR detection of GUS mRNA, the following primers were used: GUS-1, 5'-AGA CTG TAA CCA CGC GTC TC-3' and GUS-2, 5'-CCG ACA GCA GTT TCA TCA ATC-3' (Vroemen et al., 1998).

\section{AtTLP1 knockout mutant SGT5141}

Knockout mutant SGT5141 (in Ler-0 background) was selected from the database of gene trap lines carrying $D s$ element insertions that was previously described (Parinov et al., 1999) and can be accessed via http://www.plantcell.org/cgi/content/full/11/12/2263/DC1/1. The $D s$ element in SGT5141 was found to be inserted 399 bp before the stop codon of the AtTLPI gene, leading to a truncated protein 133 amino acids shorter than the mature AtTLP1 of 255 amino acids. Homozygous SGT5141 plants were tested for their ability to express rhizobacteria-mediated ISR as described above.

\section{Results}

Screening transposants for $\mathrm{P}$. fluorescens WCS417r-induced GUS expression

In total 200 gene trap (WGT) transposants and 400 enhancer trap (WET) transposants were examined for GUS expression patterns in roots and leaves after colonization of the roots by ISRinducing WCS417r bacteria. The gene trap lines were constructed to detect expression of a chromosomal gene with a transposon insertion within 

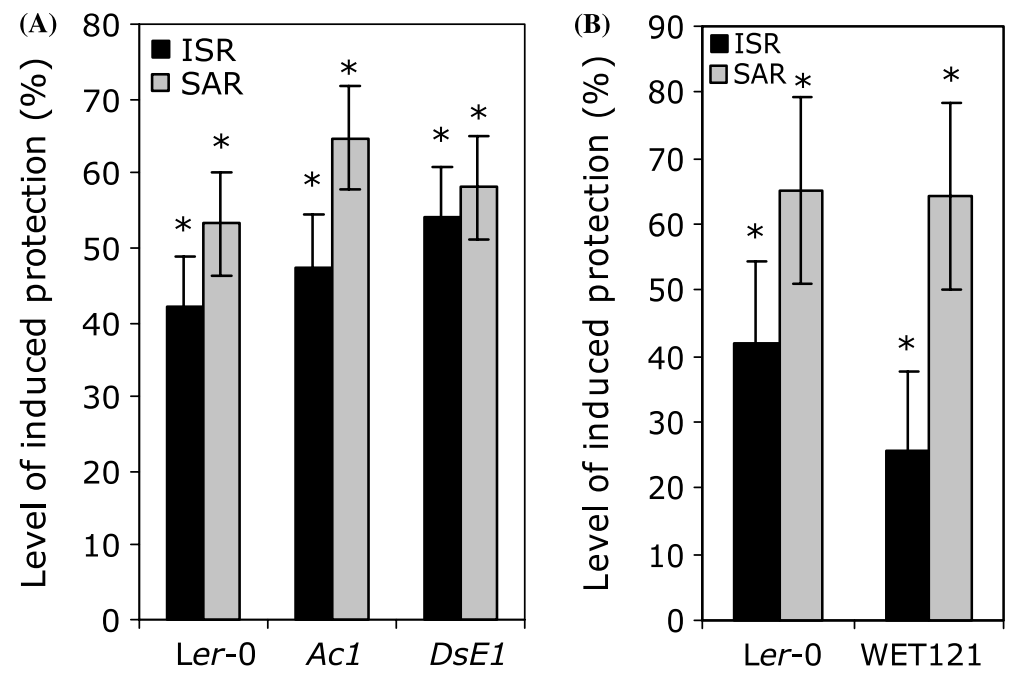

Figure 1. Levels of induced protection against Pst DC3000 as a result of $P$. fluorescens WCS417r-mediated ISR and Pst DC3000(avrRpt2)-induced SAR in wild-type Ler-0 plants, the starter lines $A c 1$ and $D s E 1$ (A) and enhancer trap line WET121 (B). ISR was induced by growing plants for 3 weeks in soil containing ISR-inducing P. fluorescens WCS417r bacteria at $5 \times 10^{7} \mathrm{cfu} \mathrm{g}^{-1}$. Fiveweek-old plants were challenge inoculated with a bacterial suspension of virulent $P s t$ DC3000 at $2.5 \times 10^{7} \mathrm{cfu} \mathrm{ml}^{-1}$. Induction of SAR was performed 3 days before challenge inoculation by pressure infiltrating three lower leaves with a suspension of Pst DC3000(avrRpt2) bacteria at $10^{7} \mathrm{cfu} \mathrm{m}^{-1}$. Four days after challenge inoculation, the percentage of diseased leaves was determined and the level of induced protection calculated on the basis of the reduction in the percentage of diseased leaves per plant relative to challenged control plants (set at $100 \%$ ). The absolute proportions of diseased leaves of control-treated Ler- $0, A c 1$, and DsEl in (A) and Ler-0 and WET121 in (B) were 61.9, 48.4, 48.2, 69.5, and 57.7, respectively. Asterisks indicate statistically significant differences compared to non-induced, Pst DC3000-challenged control plants (students $t$-test: $\alpha=0.05 ; n=20$ ). Data presented are means from a representative experiment that was repeated at least twice with similar results. Error bars represent standard errors.

the transcribed region. For this purpose, the $D s$ element contained a promoterless GUS gene, whose expression relies on the transcription of the chromosomal gene in which it is inserted (Sundaresan et al., 1995; Vroemen et al., 1998). The enhancer trap lines contained a $D s$ element with the GUS gene fused to a minimal -1 to -46 bp CaMV 35S promoter, which is not active in the absence of enhancer sequences. In these lines, expression of the GUS reporter gene is dependent on insertion near chromosomal enhancer sequences (Sundaresan et al., 1995; Vroemen et al., 1998). Thus, when the $D s$ element of an enhancer trap line is inserted in the proximity of a chromosomal gene, within or outside the coding sequence, GUS gene expression can be activated.

The WGT and WET transposants were constructed in the Ler-0 background, an accession previously shown to develop ISR after colonization of the roots by WCS417r (Ton et al., 1999; Van Wees et al., 1997). Before screening the transposants, starter lines $A c 1$ and $D s E 1$ (Vroemen et al., 1998) were checked for their ability to express induced resistance against the bacterial pathogen Pst DC3000 using standard ISR and SAR bioassays (Pieterse et al., 1996). Figure 1A demonstrates that both starter lines were able to express levels of WCS417r-mediated ISR and Pst DC3000(avrRpt2)-induced SAR that are similar to those observed in wild-type Ler-0 plants, indicating that the ability to express induced resistance was not affected in these lines.

To screen transposants for GUS expression patterns, 2-week-old seedlings of the WGT and WET lines were transplanted into soil with or without ISR-inducing WCS417r bacteria. Systemic protection in ISR-expressing plants results from the continuous stimulation of the plant by ISRinducing rhizobacteria at the root surface. In Arabidopsis, full expression of WCS417r-mediated ISR in the leaves can be detected within 7 days after treatment of the roots with this rhizobacterial strain (Ton et al., 2002b). All lines were harvested 4 and 11 days after induction treatment and examined for $G U S$ expression patterns. Of the WGT lines, approximately $20 \%$ showed GUS expression, whereas approximately $35 \%$ of the WET lines stained for GUS activity. This is in 
good agreement with the percentages found by Vroemen et al. (1998). Only in enhancer trap line WET121 GUS expression was specifically induced by the WCS417r treatment. In this line, specific GUS activity was apparent in the roots 4 days after colonization by WCS417 $r$ bacteria (Figures 2A-B). Interference contrast microscopy revealed that WCS417r-induced GUS activity was localized in the root vascular bundle (Figure 2C). No GUS activity was detected in leaves or reproductive organs (data not shown), indicating that the observed WCS417r-induced GUS expression was root specific.

\section{Specificity of rhizobacteria-induced GUS expression in WET121}

Development of rhizobacteria-mediated ISR is dependent on the plant/rhizobacterium combination, suggesting that recognition of the rhizobacteria by the plant is involved in the induction of ISR. Previously, rhizobacterial strains $P$. fluorescens WCS374r and Pseudomonas putida WCS358r were demonstrated to trigger ISR in radish and Arabidopsis, respectively (Leeman et al., 1995; Van Wees et al., 1997). To investigate whether these strains also activate GUS expression in WET121, they were applied to the roots of WET121 plants that were grown on vertical agar plates. Escherichia coli S17 bacteria that colonize Arabidopsis roots but do not induce ISR, were used as a control. Figures 2D-F show that WCS358r and WCS374r induced a similar GUS expression pattern in WET121 as did WCS417r. Application of E. coli bacteria did not result in $G U S$ expression. Application of the Pseudomonas and $E$. coli bacterial strains to roots of soil-grown plants supported these findings (data not shown). The observation that E. coli strain S17 did not activate $G U S$ expression suggests that physical colonization of the roots by bacteria per se is not sufficient to activate the GUS reporter gene in WET121. Apparently, specific components of the Pseudomonas rhizobacteria are required for the activation of the gene.

\section{Chemical induction of GUS expression in WET121}

WCS417r-mediated ISR in Arabidopsis functions independently of SA but requires responsiveness to the plant hormones JA and ET (Pieterse et al.,
1996, 1998). To investigate whether $G U S$ expression in WET121 is regulated also by these signals, seedlings were grown on MS-agar containing $0.01 \mathrm{mM}$ methyl jasmonate (MeJA), $0.1 \mathrm{mM}$ of the ET precursor ACC, or $0.1 \mathrm{mM} \mathrm{SA}$. The concentrations used were previously demonstrated to activate JA-, ET-, or SA-responsive gene expression, respectively, and to induce resistance against Pst DC3000 (Van Wees et al., 1999). Figures 2G-I show that MeJA and SA did not induce GUS expression in WET121 seedlings. However, when incubated in the presence of ACC, WET121 seedlings showed a pronounced GUS expression pattern in the root vascular bundle, similar to that observed in rhizobacteriatreated WET121 plants (Figure 2J). These results indicate that the Ds element in WET121 is inserted in the vicinity of a rhizobacteria-inducible, ETresponsive gene.

\section{Molecular analysis of WET121}

To identify the gene activated in response to rhizobacteria and ACC, the number of $D s$ elements in the genomic DNA of WET121 was determined. Genomic DNA of WET121 and wildtype Ler-0 plants was digested with PstI, which cuts once in the $D s$ element outside of the GUS gene. Southern blot analysis using the GUS coding sequence as a probe, indicated that WET121 carried a single copy of the $D s$ element (Figure 3A).

To determine the location of the $D s$ element in the genome of WET121, genomic DNA flanking the $D s$ insertion was amplified by thermal asymmetric interlaced (TAIL) PCR, essentially as described previously (Liu et al., 1995; Vroemen et al., 1998). Figure 3B shows that TAIL-PCR resulted in specific PCR products in the secondary and tertiary round of TAIL-PCR. Sequencing of the flanking DNA revealed that the $D s$ element was inserted into chromosome 4 (Figure 3C). As is the case for most of the enhancer trap lines (Vroemen et al., 1998), the Ds element was not inserted into an open reading frame. Thus, the rhizobacteria- and ACC-induced GUS expression was the result of the activity of (an) enhancer sequence(s) in the vicinity of the $D s$ element. Candidate genes in close proximity to the $D s$ element were a gene encoding a thaumatin-like protein (AtTLP1; At4g24180), a gene encoding a 

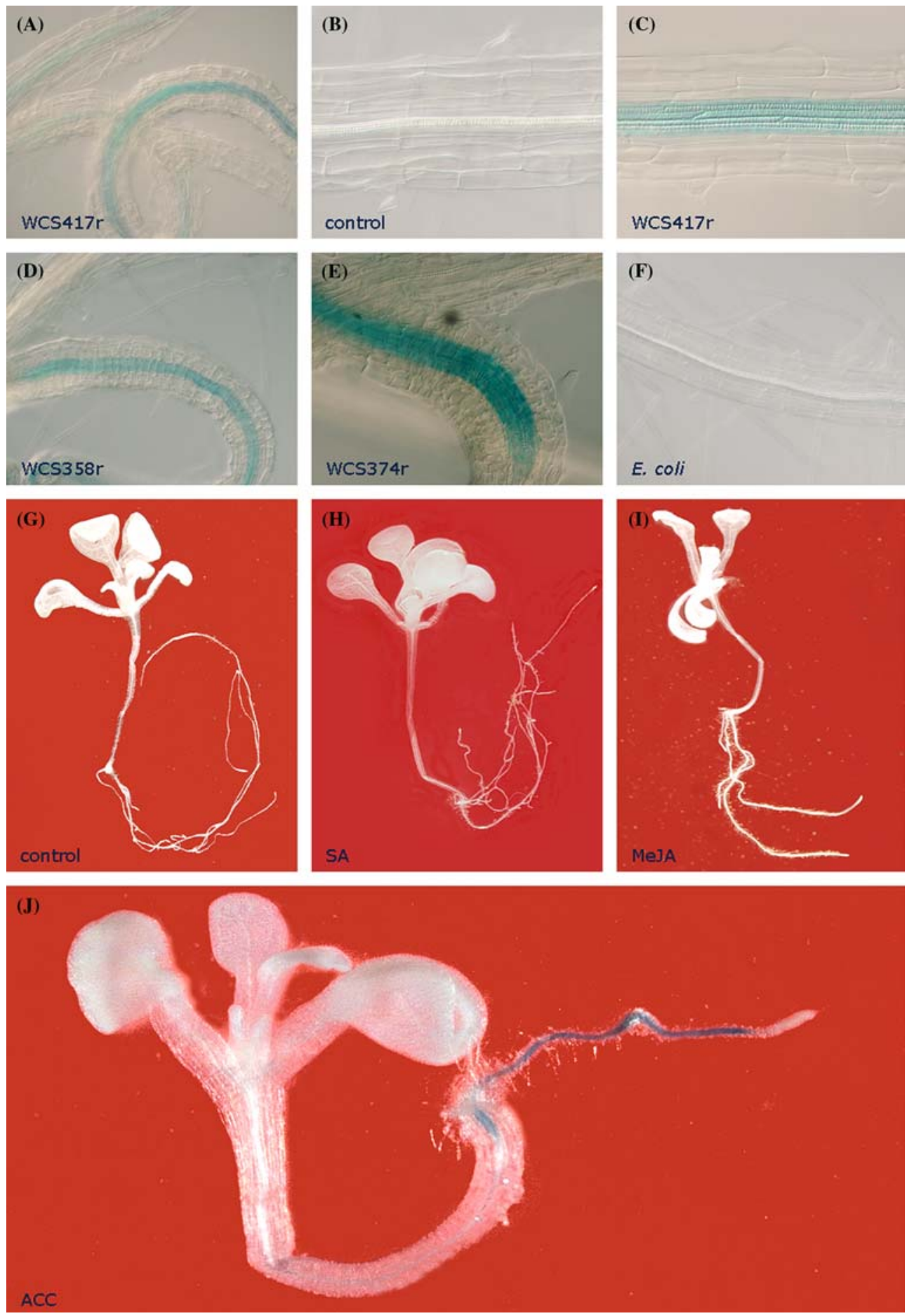

Figure 2. GUS expression patterns in enhancer trap line WET121. Pictures show light microscopic images (A, D-F), interference contrast microscopic images $(\mathrm{B}-\mathrm{C})$, or photographs $(\mathrm{G}-\mathrm{J})$ of roots grown in soil with P. fuorescens WCS417r (A + C); roots grown in soil without rhizobacteria (B); roots grown on MS-agar with P. putida WCS358r (D); roots grown on MS-agar with P. fluorescens WCS374r (E); roots grown on MS-agar with E. coli S17 (F); seedling grown on MS-agar (G) with $0.1 \mathrm{mM} \mathrm{SA}(\mathrm{H})$, $0.01 \mathrm{mM}$ MeJA (I), or $0.1 \mathrm{mM}$ ACC (J). 


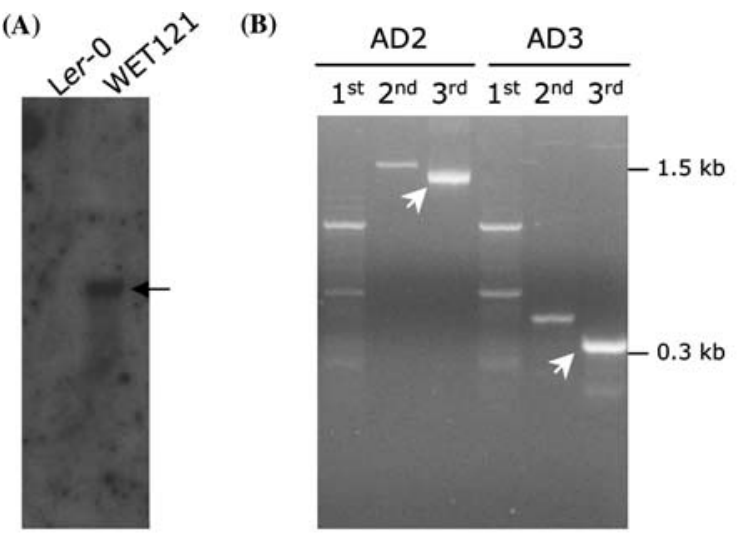

(C)

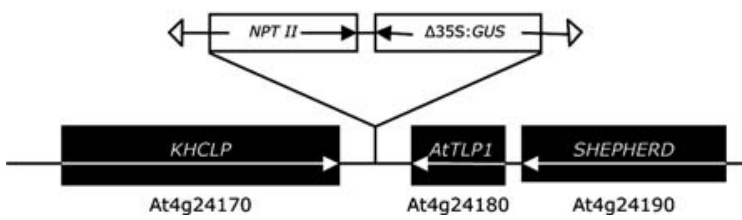

Figure 3. Molecular analysis of enhancer trap line WET121. (A) Southern blot of $10 \mu \mathrm{g}$ of genomic DNA from Ler-0 and WET121. The DNA was digested with Pst $\mathrm{I}$, blotted and hybridized with the entire GUS coding sequence. (B) Ethidium bromide-stained agarose gel showing the TAIL-PCR products after the primary (1st), the secondary (2nd), and the tertiary (3rd) round of TAIL-PCR with arbitrary degenerated primers $\mathrm{AD} 2$ and $\mathrm{AD} 3$, and nested $D s$ specific primers Ds5-1 (1st), Ds5-2 (2nd), and Ds5-3 (3rd). In the secondary round of TAIL-PCR a specific PCR product appeared with both the $\mathrm{AD} 2$ and the AD3 primer combinations. These specific PCR products were further amplified in the tertiary round of TAIL-PCR, yielding PCR products of ca. $1.5 \mathrm{~kb}$ (with AD2) and $0.3 \mathrm{~kb}$ (with AD3). The PCR products in the tertiary round are shorter then those in the secondary round and are conform the predicted size reductions, indicating that the flanking sequences of the $D s$ element in WET121 were amplified successfully. Sequencing of these TAIL-PCR products revealed the flanking sequences of the $D s$ element insertion in WET121. (C) Schematic representation of the flanking sequences of the $D s$ element in WET121. Genes in the vicinity of the $D s$ element insertion encode a kinesin heavy chain-like protein (KHCLP), a thaumatin-like protein (AtTLP1) and the HSP90 type protein SHEPHERD.

kinesin heavy chain-like protein (KHCLP; At4g24170), and SHEPHERD (At424190) encoding a HSP90 type protein (Ishiguro et al., 2002).

Because the Ds element in WET121 was not inserted in, or in the immediate vicinity of an open-reading frame, it was expected that WET121 would show normal ISR in response to colonization of the roots by WCS417r. Figure 1B shows that indeed, WET121 developed normal levels of ISR against $P$ st DC3000.
GUS and AtTLP1 are co-regulated in WET121

Insertions in enhancer trap lines result in $G U S$ expression when the $D s$ element is inserted either upstream or downstream of an active gene. Enhancers are known to act in an orientationindependent manner. Thus, insertions in either orientation can result in GUS expression (Vroemen et al., 1998). To identify the gene that is responsible for the WCS417r- and ACC-induced activation of the GUS gene in WET121, the expression of SHEPHERD, AtTLP1, and KHCLP in control and ACC-treated WET121 plants was analyzed. Northern blot analysis showed that SHEPHERD is expressed in roots and leaves of both control- and ACC-treated plants (Figure 4A). This was incompatible with the WCS417r- and ACC-induced GUS expression pattern observed in WET121 and disqualified SHEPHERD as a candidate gene for co-regulation of the GUS gene.

KHCLP and AtTLP 1 transcripts could not be detected by northern blot analysis. Therefore, their expression patterns were examined by RT-PCR. Again, KHCLP mRNA could not be detected in roots of control-, WCS417r-, and ACC-treated plants (data not shown). Therefore, AtTLP1 was the only candidate gene left in the close vicinity of the inserted $D s$ element that may be responsible for the vascular tissue-specific expression of the GUS gene in WCS417r- or ACC-treated roots. Indeed, AtTLP1 transcripts accumulated in the roots upon treatment with ACC, which clearly correlated with the concomitant increase in $G U S$ mRNA levels (Figure 4B). In the roots of untreated control plants, no AtTLPI mRNA could be detected. Moreover, both AtTLPI and GUS transcripts could not be detected in the leaves of control- and ACC-treated plants (data not shown). The strong correlation between the root-specific expression of AtTLP1 and GUS strongly suggest that $G U S$ expression observed in the root vascular bundle of WET121 is regulated by an enhancer of the AtTLPI gene and identifies the AtTLPI gene as a plant gene that is activated in the roots by ACC and fluorescent Pseudomonas spp.

\section{AtTLP1 encodes a PR-S type protein}

The AtTLPl gene encodes a thaumatin-like protein belonging to the PR-5 family of pathogenesis 

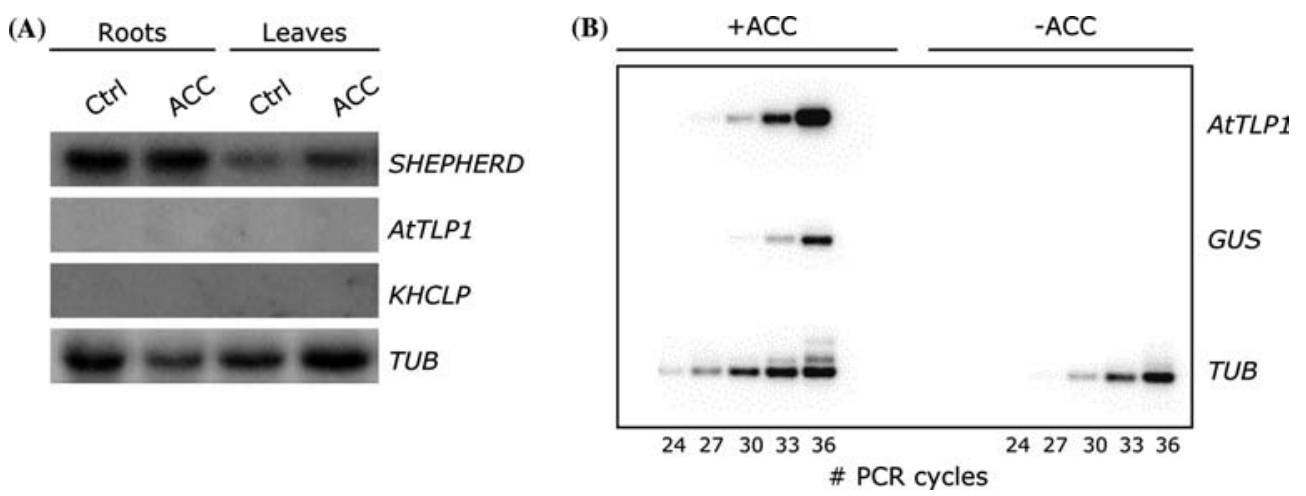

Figure 4. Expression analysis of genes flanking the $D$ s element insertion in WET121. Seedlings of WET121 were grown vertically on MS-agar plates for 12 days. Subsequently, $2 \mathrm{ml}$ of water (Ctrl) or a solution containing $1 \mathrm{mM}$ ACC was added onto the plates. Six days later, roots and leaves were harvested separately for RNA extraction. (A) Northern blot analysis of SHEPHERD, AtT$L P 1$, and KHCLP mRNA in roots and leaves of WET121 plants grown with or without ACC. The blot was hybridized with genespecific probes and stripped between hybridisations. To check for equal loading, the blot was hybridized with a gene-specific probe for $\beta$-tubulin $(T U B)$. (B) RT-PCR analysis of AtTLP1, GUS, and TUB transcript levels in control- and ACC-treated roots of WET121. Shown are PCR products in the RT-PCR mixture after 24-36 PCR cycles (negative photograph of ethidium bromidestained agarose gel).

related proteins. The putative AtTLP1 protein contains 255 amino acids and has a predicted molecular mass of $26.9 \mathrm{kD}$ and a theoretical $\mathrm{pI}$ of 4.69 (http://mips.gsf.de/proj/thal/db/). Comparison of the predicted amino acid sequence with sequences in the databank revealed that it shares highest homology with the predicted amino acid sequence of the thaumatin-like isolog gene AtTLI (At4g38660; 70\% identity) (Figure 5). AtTLP1 shares $56 \%$ identity at the amino acid level with the previously identified Arabidopsis AtPR-5 protein that is associated with SAR (Uknes et al., 1992), and is homologous to other proteins belonging to the PR-5 family, including tobacco NtOsmotin (Singh et al., 1989) (40\% identity) and the tomato LePR-5x protein (39\% identity), which was found to accumulate in the xylem sap of F. oxysporum-infected tomato plants (Rep et al., 2002). The homology with the previously characterized PR-5 type proteins NtOsmotin and LePR$5 \mathrm{x}$ is relatively low. Figure 6 shows a phylogenetic tree of all 24 Arabidopsis PR-5 type proteins and selected PR-5 type proteins from other plant species. Within this tree, AtTLP1 clusters together with 7 other PR-5 type proteins of Arabidopsis, some of which have not been characterized so far. To investigate whether the eight genes of the AtTLP1 cluster may have redundant functions, we analyzed their expression profile using the Arabidopsis microarray database and analysis toolbox Genevestigator (Zimmermann et al., 2004). With this toolbox it is possible to study how genes are co-expressed over selected microarrays in the database, and to which specific biotic and abiotic stress(es) the genes of interest are responsive. Comparison of the expression pattern of AtTLP1 with that of the seven other $P R$-5-like genes (i.e. At1g20030, At1g75800, At2g17860, At4g36000, At4g36010, At4g38660, At4g38670) in 1434 Affymetrix 25k ATH1 GeneChip hybridization experiments, revealed that none of the $7 P R$-5-like genes tested was co-expressed with AtTLPI (data not shown). While AtTLPI expression was only detectable in the roots, the other seven genes were either expressed in other tissues, or were responsive to biotic or abiotic stresses.

\section{Effect of AtTLP1 knockout mutation}

Previously, Parinov et al. (1999) generated a randomly mutagenized collection of gene trap lines carrying $D s$ element insertions throughout the Arabidopsis genome. This collection contained a knockout mutant line (SGT5141) with a $D s$ element inserted $133 \mathrm{bp}$ upstream of the stop codon of the AtTLP1 gene, leading to a truncated protein. The presence of the insertion was verified by TAIL-PCR as described for the WET121 line (data not shown). To examine the effect of this AtTLPI knockout mutation on the effectiveness of WCS417r-mediated ISR, ISR bioassays were performed with wild-type Ler-0 and mutant SGT5141 


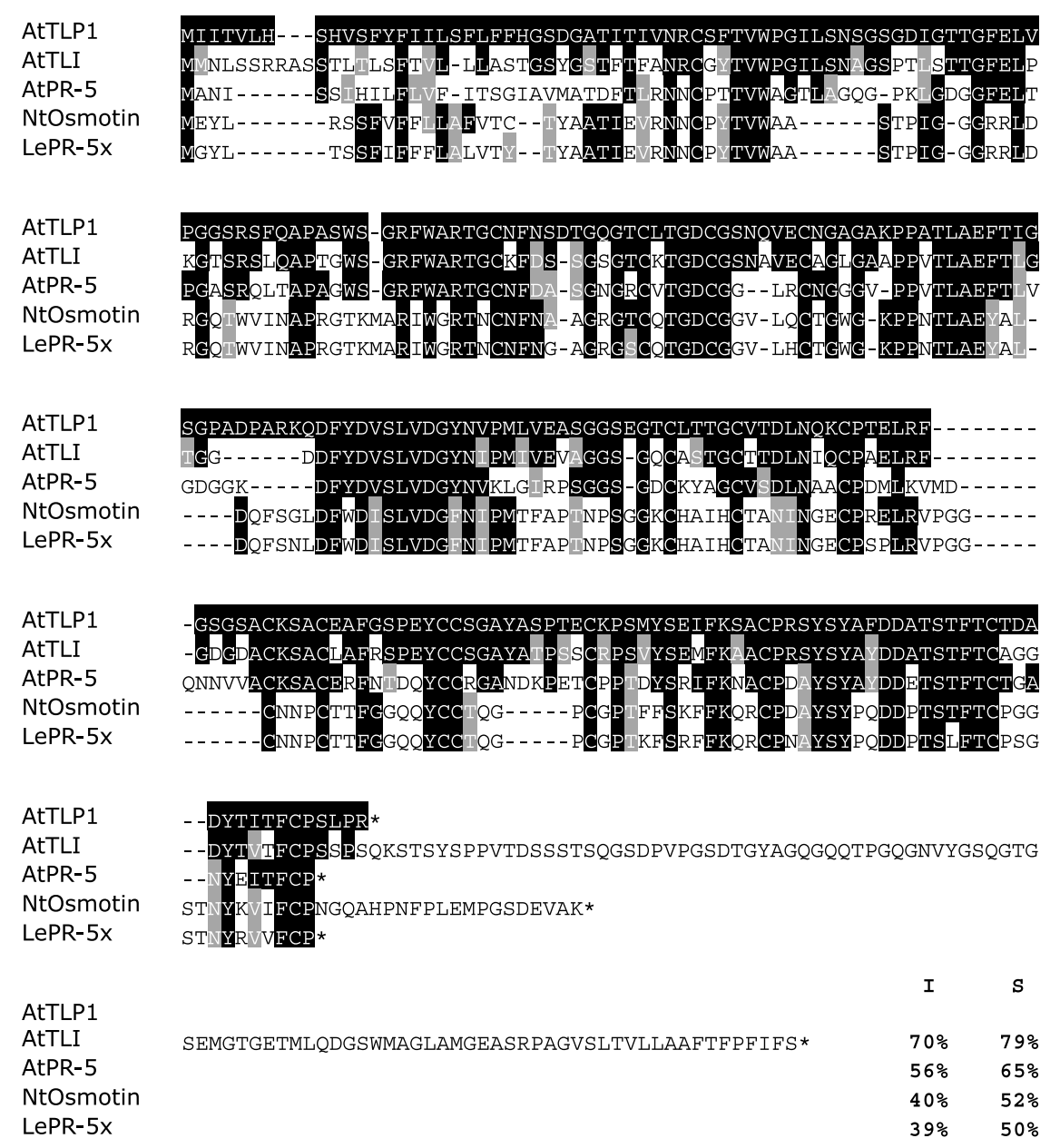

Figure 5. Comparison of the predicted amino acid sequence of AtTLP1 with other PR-5 type proteins. The alignment shows the amino acid sequences of several PR-5 type proteins. Sequences are from Arabidopsis AtTLP1 (AGI number At4g24180), Arabidopsis AtPR-5 (AGI number Atlg75040; Uknes et al. (1992)), Arabidopsis AtTLI (AGI number At4g38660), tobacco NtOsmotin (GeneBank accession number X95308; Singh et al. (1989)), and LePR-5x (GeneBank accession number AAM23272; Rep et al. (2002)). Numbers above the alignments correspond to amino acid positions in AtTLP1. Black shading indicates amino acids identical to the AtTLP1 template, and gray shading indicates amino acids that are similar to the AtTLP1 template.

plants. For comparison, the effectiveness of pathogen-induced SAR was also examined. Figure 7 shows that SGT5141 developed levels of SAR similar to wild-type Ler-0. Moreover, SGT5141 showed the same level of ISR after colonization of the roots by WCS417r as did wild-type plants. Thus, the $D s$ insertion within the AtTLPl gene had no effect on the ability of SGT5141 to express ISR.

\section{Discussion}

Colonization of the roots of Arabidopsis by selected strains of fluorescent Pseudomonas spp. leads to an enhanced defensive capacity that is effective against a broad range of foliar pathogens (Pieterse et al., 2002). In contrast to pathogeninduced SAR, rhizobacteria-mediated ISR is not associated with induced expression of $P R$ genes (Pieterse et al., 1996, 1998; Van Wees et al., 1999, 1997; Verhagen et al., 2004). In search for genes that are specifically activated during ISR, we used a $A c / D s$-based gene/enhancer trap system, developed according to Sundaresan et al. (1995) by Vroemen et al. (1998), to detect genes that are specifically expressed in response to colonization of the roots by ISR-inducing WCS417r bacteria. Based on GUS activity staining, we identified an enhancer trap line that shows specific GUS 
expression in the vascular bundle of Arabidopsis roots upon colonization by fluorescent Pseudomonas spp. strains WCS417r, WCS358r, and WCS374r, but not after colonization of the roots by ISR-non-inducing E. coli bacteria (Figure 2). These results indicate that colonization of the roots by bacteria per se is not sufficient to activate the GUS reporter gene in WET121. Apparently, specific components of the Pseudomonas rhizobacteria are required for the activation of the gene. The ET precursor ACC specifically activated the GUS gene as well (Figure 2). The specific ACCinduced activation of the GUS gene in vascular bundle of the roots closely resembled the GUS expression pattern induced by the rhizobacteria. It can, thus, be concluded that the GUS gene on the Ds element in WET121 is inserted in the vicinity of a rhizobacteria-inducible, ET-responsive gene.

The GUS reporter gene in the $A c / D s$-transposon based gene/enhancer trap system used in this study responds to cis-acting transcriptional signals at the site of integration. These cis-acting transcriptional signals predominantly come from a gene in the close vicinity of the inserted $D s$ element (Ramachandran and Sundaresan, 2001). The AtTLPl gene, encoding a thaumatin-like protein that belongs to the evolutionarily conserved class of PR-5 proteins (Van Loon and Van Strien, 1999), was the only candidate gene that was coordinately activated with the GUS reporter gene in response to ACC treatment (Figures 3 and 4). Moreover, like the GUS reporter gene, AtTLP1 showed a root-specific expression pattern in response to ACC treatment. These results indicate that the GUS reporter gene in transposant WET121 is regulated by an enhancer of the AtTLP1 gene and identifies the AtTLP1 gene as a plant gene that is activated in the vascular bundle of Arabidopsis roots by ACC and fluorescent Pseudomonas spp.

Rhizobacterial strains WCS417r, WCS358r, and WCS374r all induced the expression of the GUS reporter gene in WET121. In the case of WCS417r and WCS358r this nicely correlates with their ability to trigger ISR in Arabidopsis (Van Wees et al., 1997). However, strain WCS374r, which consistently induces ISR in radish (Leeman et al., 1995), but shows variable results in Arabidopsis (Van Wees et al., 1997; Ran et al., 2000), activated the GUS reporter gene in WET121 as well. Therefore, these results did not allow a conclusion concerning the importance of the concomitantly expressed AtTLP1 gene in the onset or expression of ISR. To gain insight in the role of AtTLP1 in the onset of ISR, AtTLP1 knockout mutant plants were tested on their ability to express WCS417r-induced ISR. Knockout mutant plants (Figure 7), as well as AtTLP1-overexpressing transgenic plants (data not shown) developed normal levels of WCS417r-induced ISR against Pst DC3000, indicating that the rhizobacteriainduced AtTLP1 gene is unlikely to play a crucial role in ISR against this foliar pathogen.

Previously, Hase et al. (2003) described another response of Arabidopsis to Pseudomonas bacteria that seems to be unrelated to the ability to induce ISR. Leaves of plants of which the roots were colonized by WCS417r, WCS358r, or WCS374r bacteria showed an enhanced capacity to convert the ET precursor ACC to ET, leading to a potentiated expression of the ET-responsive genes PDF1.2 and HEL after treatment of the leaves with $1 \mathrm{mM} \mathrm{ACC}$, and a significantly higher level of ET emission after pathogen challenge. This enhanced ACC-converting capacity was also apparent in the ISR-impaired mutants jar $1-1$ and nprl-1 after treatment of the roots with Pseudomonas bacteria. These induced plant responses to colonization of the roots by nonpathogenic Pseudomonas bacteria demonstrate that Arabidopsis plants perceive signals from the rhizobacteria that are present on the root surface, and translate these signals into local and systemic responses. The exact role of these rhizobacteriainduced plant responses in induced resistance or other plant growth-promoting characteristics that are associated with these plant-PGPR interactions, remains to be further elucidated.

The AtTLPI gene encodes a thaumatin-like protein, which belongs to the evolutionarily conserved class of PR-5 proteins (Van Loon and Van Strien, 1999). A large number of PR-5 proteins from different plant species has been isolated and characterized (Anžlovar and Dermastia, 2003), all of which show similarity to the sweet-tasting protein thaumatin present in the fruits of the tropical shrub Thaumatococcus danielii (Van der Wel and Loeve, 1972). Several PR-5 proteins have been shown to possess antimicrobial activity in vitro (Woloshuk et al., 1991; Anžlovar and Dermastia, 2003), or in vivo (Liu et al., 1994), or appear to be involved in osmotic adaptation 


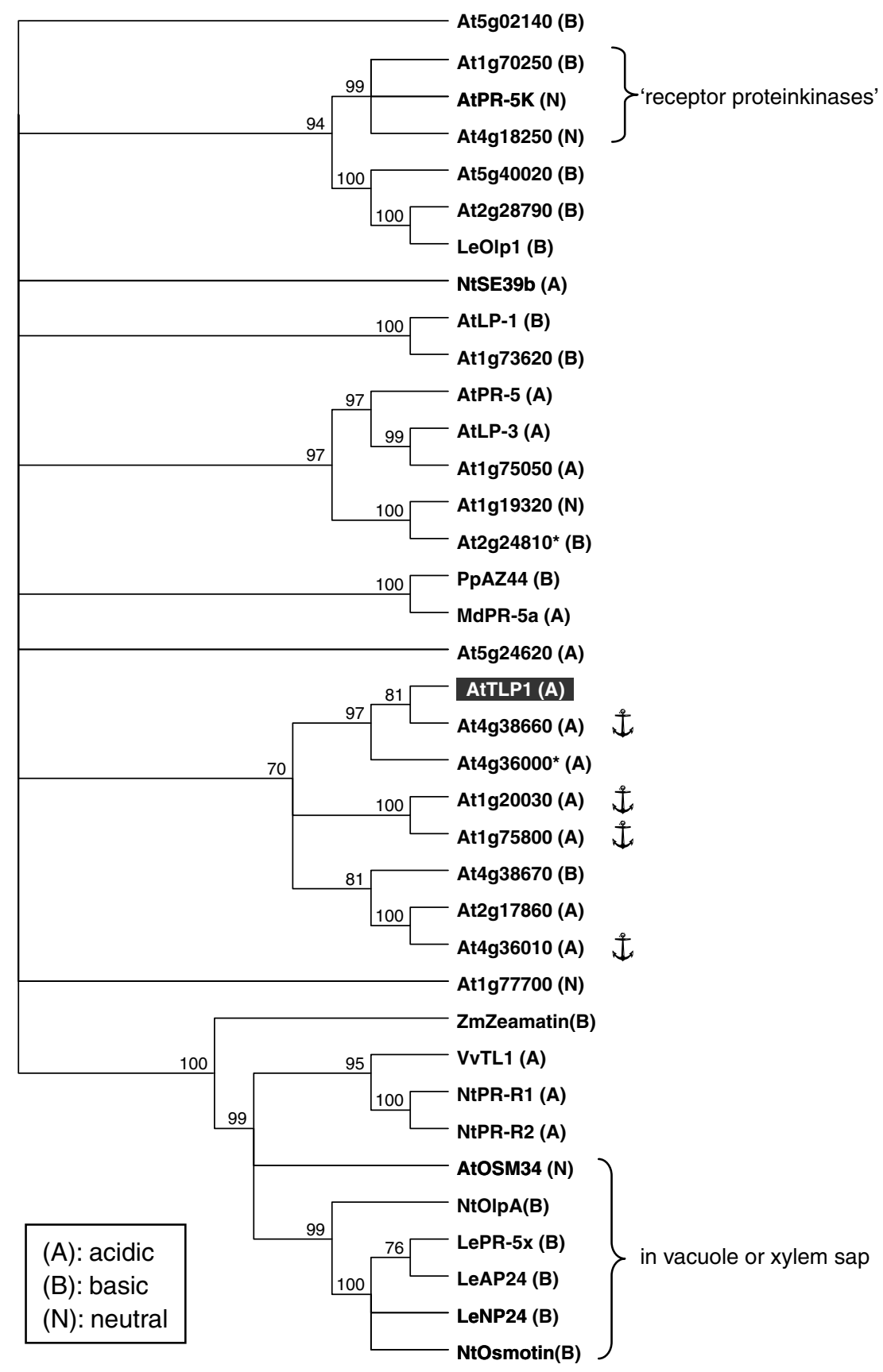

(Singh et al., 1987; Anžlovar and Dermastia, 2003). Besides constitutive and tissue-specific $P R$ 5 genes, many $P R-5$ genes are induced upon biotic or abiotic stresses (Van Loon and Van Strien, 1999). Among the 24 putative PR-5 proteins in Arabidopsis, AtTLP1 clusters together with 7, so far uncharacterized homologues (Figure 6). Comparison of expression profiles of the eight $P R-5-$ like genes in the AtTLPl cluster showed that AtTLP1 is not co-expressed with any of the seven homologues in the cluster, suggesting that the function of $A t T L P 1$ is not redundant. The amino acid sequence homology of AtTLP1 with the previously characterized acidic AtPR-5 protein (Uknes et al., 1992) is relatively low (56\% identity), suggesting that the two proteins have different 
functions. This is supported by the fact that the expression of AtTLPI is regulated by ET (Figures 2 and 4), whereas AtPR-5 is controlled in a SA-dependent manner (Uknes et al., 1992). Moreover, AtPR-5 is not activated in response to colonization of the roots by ISR-inducing WCS417r bacteria (Pieterse et al., 1996, 1998; Van Wees et al., 1997). AtTLP1 is specifically activated in the vascular bundle upon colonization of the roots by Pseudomonas bacteria. Previously, the tomato PR-5 type protein LePR-5x was found to accumulate in xylem sap of tomato plants after root infection with F. oxysporum (Rep et al., 2002). However, in contrast to the putative AtTLP1 protein, LePR-5x is basic and has only low homology with AtTLP1 (39\% identity). Thus, although both AtTLP1 and LePR-5x are predicted to act in the vascular bundle, it is not known whether they have a similar function.

What might be the role of induced AtTLP1 gene expression in roots that are colonized by Pseudomonas bacteria? Most of the isolated PR-5 type proteins possess antimicrobial activity in in vitro assays, in which they inhibit germination and cause lysis of spores of fungal and oomycete pathogens (Woloshuk et al., 1991; Abad et al., 1996). Although the specific mode of action of PR5 type proteins is not known, they are thought to be capable of permeabilizing fungal membranes
(Anžlovar and Dermastia, 2003). Because AtTLP1 is specifically expressed in the root vascular bundle, the putative AtTLP1 protein may have a local antimicrobial function.

Transposons have been used extensively for insertional mutagenesis of several plant species in order to identify and characterize genes conferring a mutant phenotype (Ramachandran and Sundaresan, 2001). A useful aspect of the $A c / D s$-transposon based gene/enhancer trap system described by Sundaresan et al. (1995) is that the transposons carry a GUS reporter gene that can respond to cis acting transcriptional signals at the site of integration, thereby facilitating the identification of genes based on their expression pattern, rather than on their mutant phenotype. Another advantage of this system is that it may allow the identification of genes that, due their low or restricted expression patterns, remain undetected in other differential screening methods or DNA microarray analyses. Despite the relatively small screen of 200 gene trap end 400 enhancer trap lines we were able to identify AtTLPI as an example of such a gene. The GUS gene in enhancer trap line WET121, which is activated in cis by the AtTLP1 gene in the vicinity of the $D s$ insertion, was expressed in a tissue-specific manner in the roots in response to colonization by non-pathogenic rhizobacteria. Rhizobacteria-induced expression

Figure 6. Phylogenetic tree of Arabidopsis PR-5 proteins and selected PR-5 proteins from other plant species. All 24 predicted proteins of Arabidopsis with a PR-5 ("thaumatin-like") domain present in The Arabidopsis Information Resource (www.arabidopsis.org) were aligned with selected PR-5 proteins from other plant species. Additions to the core PR-5 consensus sequence at $\mathrm{N}$-termini (signal sequences) and C-termini (vacuolar targeting sequences or other extensions beyond the conserved sequence "FCP") were trimmed. This alignment was used to construct a phylogenetic tree using Neighbour-Joining. A PR-5-like protein from Caenorhabditis elegans (accession AAF60831) was used to root the tree. Based on the pI of the core sequences, the proteins were classified as acidic ( $\mathrm{pI}<5.5$, “A"), neutral $(5.5<\mathrm{pI}<7.5$, "N") or basic (pI > 7.5, "B"). Four Arabidopsis PR-5 proteins have long C-terminal extensions (71-100 residues) ending with a stretch of about 20 hydrophobic residues that could serve as a membrane anchor (e.g. AtTLI; At4g38660 in Figure 5). In the figure, these are indicated with an anchor. Three Arabidopsis proteins that have a central hydrophobic region and a C-terminal protein kinase domain characteristic of receptor protein kinases (Wang et al., 1996) group together based on their PR-5 core sequence. Published sequences are referred to by protein names: PR-5 (Uknes et al., 1992), PR-5K (Wang et al., 1996), OSM34 (Capelli et al., 1997), LP-1 (Hu and Reddy, 1995), LP-3 (Hu and Reddy, 1997) from Arabidopsis; Olp1 (Chen et al., 1996), NP24 (King et al., 1988), AP24 (Ruiz-Medrano et al., 1992) and PR-5x (Rep et al., 2002) from tomato; Osmotin (Singh et al., 1989), SE39b (Kuboyama et al., 1997), PR-R1 (Payne et al., 1988), and PR-R2 (Cornelissen et al., 1986) from tobacco; Zeamatin (Richardson et al., 1987) from maize; PpAZ44 (Ruperti et al., 2002) from peach; MdPR-5a (Oh et al., 2000) from apple; VvTL1 (Tattersall et al., 1997) from grape. All sequence names are preceded by species abbreviations (At: Arabidopsis, Le: tomato, Md: apple, Nt: tobacco, Pp: peach, Vv: grape, Zm: maize). Bootstrap percentages are provided for branches receiving $70 \%$ or more support. Branches with less support were collapsed because in these cases branche sequence was considered to be too unreliable. Note: In two genes (At2g24810 and At4g36000) proposed introns were ignored to optimize the alignment of the respective translation products with the other proteins. Instead of the large internal deletions in coding sequences due to the presence of introns in the current gene models, this led to a single stop codon in the case of At $4 \mathrm{~g} 36000$ and an internal deletion of only 28 bp (thus a frameshift) in the case of At2g24810. Both genes are therefore likely to be pseudogenes and are marked with an asterisk $\left(^{*}\right)$ in the tree. 


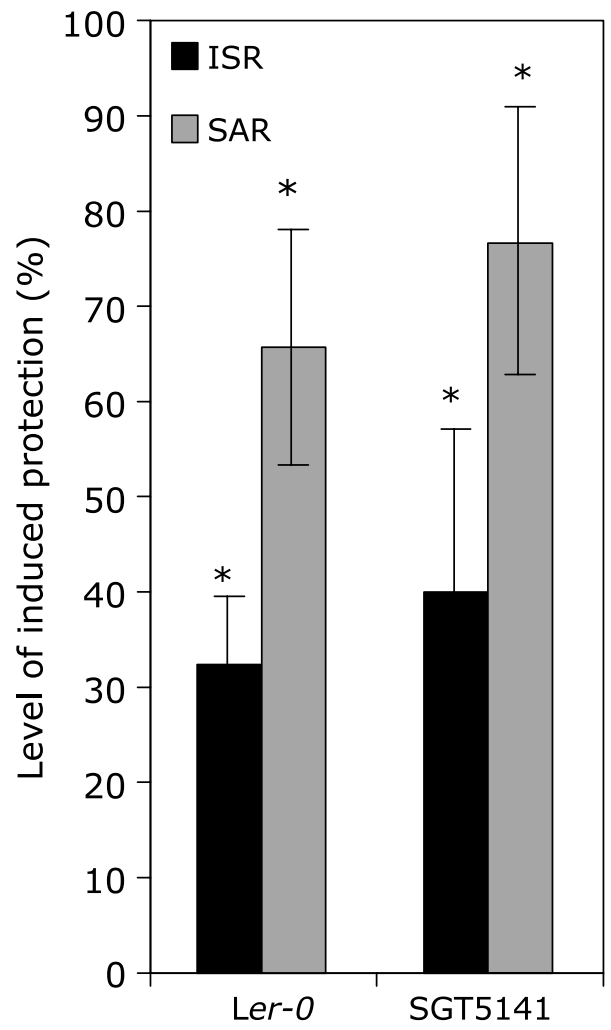

Figure 7. Levels of induced protection against Pst DC3000 as a result of P. fluorescens WCS417r-mediated ISR and pathogen-induced SAR in Ler-0 and the AtTLP1 knockout mutant SGT5141. Four days after challenge inoculation, the percentage of diseased leaves was determined and the level of induced protection calculated on the basis of the reduction in the percentage of diseased leaves per plant relative to challenged control plants (set at $100 \%$ ). The absolute proportions of diseased leaves of control-treated Ler-0 and SGT5141 plants were 44.0 and 32.3 , respectively. For details see legend to Figure 1.

levels of AtTLP1 were below the detection limit of Affymetrix GeneChip hybridizations when total RNA from roots was used as template for probe preparations (Verhagen et al., 2004). Thus, screening of the $A c / D s$-based gene/enhancer trap system can have an added value when compared to other methods for gene discovery.

\section{Acknowledgements}

We thank Dr Casper Vroemen for kindly providing the gene trap and enhancer trap lines, and Martin de Vos and Sjoerd van der Ent for critically reading the manuscript. This research was supported, in part, by grant BIO4-CT97-2120 of the European Commission Fourth Framework.

\section{References}

Abad, L.R., Paino D'Urzo, M., Lin, D., Narasimhan, M.L., Renveni, M., Zhu, J.K., Niu, X., Singh, N.K., Hasegawa, P.M. and Bressan, R.A. 1996. Antifungal activity of tobacco osmotin has specificity and involves plasma membrane permeabilization. Plant Sci. 118: 11-23.

Anžlovar, S. and Dermastia, M. 2003. The comparative analysis of osmotins and osmotin-like PR-5 proteins. Plant Biol. 5: 116-124.

Bigirimana, J. and Höfte, M. 2002. Induction of systemic resistance to Colletotrichum lindemuthianum in bean by a benzothiadiazole derivative and rhizobacteria. Phytoparasitica 30: 159-168.

Capelli, N., Diogon, T., Greppin, H. and Simon, P. 1997. Isolation and characterization of a cDNA clone encoding an osmotin-like protein from Arabidopsis thaliana. Gene 191: 51-56.

Chen, R., Wang, F. and Smith, A.G. 1996. A flower-specific gene encoding an osmotin-like protein from Lycopersicon esculentum. Gene 179: 301-302.

Conrath, U., Pieterse, C.M.J. and Mauch-Mani, B. 2002. Priming in plant-pathogen interactions. Trends Plant Sci. 7: 210-216.

Cornelissen, B.J., Hooft van Huijsduijnen, R.A. and Bol, J.F. 1986. A tobacco mosaic virus-induced tobacco protein is homologous to the sweet-tasting protein thaumatin. Nature 321: 531-532.

De Meyer, G., Capieau, K., Audenaert, K., Buchala, A., Métraux, J.-P. and Höfte, M. 1999. Nanogram amounts of salicylic acid produced by the rhizobacterium Pseudomonas aeruginosa 7NSK2 activate the systemic acquired resistance pathway in bean. Mol. Plant-Microbe Interact. 12: 450-458.

Dong, X.N, 2004. NPR1, all things considered. Curr. Opinion Plant Biol. 7: 547-552.

Duijff, B.J., Pouhair, D., Olivain, C., Alabouvette, C. and Lemanceau, P. 1998. Implication of systemic induced resistance in the suppression of fusarium wilt of tomato by Pseudomonas fluorescens WCS417r and by nonpathogenic Fusarium oxysporum Fo47. Eur. J. Plant Pathol. 104: 903-910.

Gaffney, T., Friedrich, L., Vernooij, B., Negrotto, D., Nye, G., Uknes, S., Ward, E., Kessmann, H. and Ryals, J. 1993. Requirement of salicylic acid for the induction of systemic acquired resistance. Science 261: 754-756.

Hase, S., Van Pelt, J.A., Loon, L.C.Van and Pieterse, C.M.J. 2003. Colonization of Arabidopsis roots by Pseudomonas fluorescens primes the plant to produce higher levels of ethylene upon pathogen infection. Physiol. Mol. Plant Pathol. 62: 219-226.

Hoagland, D.R. and Arnon, D.I. 1938. The water culture method for growing plants without soil. Calif. Agric. Exp. Stn. Bull. 347: 36-39.

$\mathrm{Hu}$, X. and Reddy, A.S. 1995. Nucleotide sequence of a cDNA clone encoding a thaumatin-like protein from Arabidopsis. Plant Physiol. 107: 305-306.

$\mathrm{Hu}$, X. and Reddy, A.S. 1997. Cloning and expression of a PR5-like protein from Arabidopsis: inhibition of fungal growth by bacterially expressed protein. Plant Mol. Biol. 34: 949-959. 
Iavicoli, A., Boutet, E., Buchala, A. and Métraux, J.-P. 2003. Induced systemic resistance in Arabidopsis thaliana in response to root inoculation with Pseudomonas fluorescens CHA0. Mol. Plant-Microbe Interact. 16: 851-858.

Ishiguro, S., Watanabe, Y., Ito, N., Nonaka, H., Takeda, N., Sakai, T., Kanaya, H. and Okada, K. 2002. SHEPHERD is the Arabidopsis GRP94 responsible for the formation of functional CLAVATA proteins. EMBO J. 21: 898-908.

King, E.O., Ward, M.K. and Raney, D.E. 1954. Two simple media for the demonstration of phycocyanin and fluorescin. J. Lab. Clin. Med. 44: 301-307.

King, G.J., Turner, V.A., Hussey, C.E. Jr., Syrkin Wurtele, E. and Lee, M. 1988. Isolation and characterization of a tomato cDNA clone which codes for a salt-induced protein. Plant Mol. Biol. 10: 401-412.

Kloepper, J.W., Leong, J., Teintze, M. and Schroth, M.N. 1980. Enhanced plant growth by siderophores produced by plant growth-promoting rhizobacteria. Nature 286: 885-886.

Knoester, M., Pieterse, C.M.J., Bol, J.F. Van Loon, L.C. 1999. Systemic resistance in Arabidopsis induced by rhizobacteria requires ethylene-dependent signaling at the site of application. Mol. Plant-Microbe Interact. 12: 720-727.

Kuboyama, T., Yoshida, K.T. and Takeda, G. 1997. An acidic 39-kDa protein secreted from stigmas of tobacco has an amino-terminal motif that is conserved among thaumatinlike proteins. Plant Cell Physiol. 38: 91-95.

Kunkel, B.N., Bent, A.F., Dahlbeck, D., Innes, R.W. and Staskawicz, B.J. 1993. RPS2, an Arabidopsis disease resistance locus specifying recognition of Pseudomonas syringae strains expressing the avirulence gene AvrRpt2. Plant Cell 5: 865-875.

Leeman, M., Van Pelt, J.A., Den Ouden, F.M., Heinsbroek, M., Bakker, P.A.H.M. and Schippers, B. 1995. Induction of systemic resistance by Pseudomonas fluorescens in radish cultivars differing in susceptibility to fusarium wilt, using a novel bioassay. Eur. J. Plant Pathol. 101: 655-664.

Liu, D., Raghothama, K.G., Hasegawa, P.M. and Bressan, R.A. 1994. Osmotin overexpression in potato delays development of disease symptoms. Proc. Natl. Acad. Sci. USA 91: 1888-1892.

Liu, Y.-G., Mitsukawa, N., Oosumi, T. and Whittier, R.F. 1995. Efficient isolation and mapping of Arabidopsis thaliana T-DNA insert junctions by thermal asymmetric interlaced PCR. Plant J. 8: 457-463.

Maurhofer, M., Reimmann, C., Schmidli-Sacherer, P., Heeb, S.D. and Défago, G. 1998. Salicylic acid biosynthesis genes expressed in Pseudomonas fluorescens strain P3 improve the induction of systemic resistance in tobacco against tobacco necrosis virus. Phytopathology 88: 678-684.

Nawrath, C., Heck, S., Parinthawong, N. and Métraux, J.-P. 2002. EDS5, an essential component of salicylic acid-dependent signaling for disease resistance in Arabidopsis, is a member of the MATE transporter family. Plant Cell 14: 275-286.

Oh, D.H., Song, K.J., Shin, Y.U. and Chung, W.I. 2000. Isolation of a cDNA encoding a $31-\mathrm{kDa}$, pathogenesisrelated 5/thaumatin-like (PR5/TL) protein abundantly expressed in apple fruit (Malus domestica cv. Fuji). Biosci. Biotechnol. Biochem. 64: 355-362.

Parinov, S., Sevugan, M., Ye, D., Yang, W.C., Kumaran, M. and Sundaresan, V. 1999. Analysis of flanking sequences from Dissociation insertion lines: a database for reverse genetics in Arabidopsis. Plant Cell 11: 2263-2270.

Payne, G., Middlesteadt, W., Williams, S., Desai, N., Parks, T.D., Dincher, S., Carnes, M. and Ryals, J. 1988. Isolation and nucleotide-sequence of a novel cDNA clone encoding the major form of pathogenesis-related protein-R. Plant Mol. Biol. 11: 223-224.

Pieterse, C.M.J. and Van Loon, L.C. 2004. NPR1: the spider in the web of induced resistance signaling pathways. Curr. Opinion Plant Biol. 7: 456-464.

Pieterse, C.M.J., Van Pelt, J.A., Ton, J., Parchmann, S., Mueller, M.J., Buchala, A.J., Métraux, J.-P. and Van Loon, L.C. 2000. Rhizobacteria-mediated induced systemic resistance (ISR) in Arabidopsis requires sensitivity to jasmonate and ethylene but is not accompanied by an increase in their production. Physiol. Mol. Plant Pathol. 57: 123-134.

Pieterse, C.M.J., Van Wees, S.C.M., Hoffland, E., Van Pelt, J.A. and Van Loon, L.C. 1996. Systemic resistance in Arabidopsis induced by biocontrol bacteria is independent of salicylic acid accumulation and pathogenesis-related gene expression. Plant Cell 8: 1225-1237.

Pieterse, C.M.J., Van Wees, S.C.M., Ton, J., Van Pelt, J.A. and Van Loon, L.C. 2002. Signalling in rhizobacteria-induced systemic resistance in Arabidopsis thaliana. Plant Biol. 4: 535-544.

Pieterse, C.M.J., Van Wees, S.C.M., Van Pelt, J.A., Knoester, M., Laan, R., Gerrits, H., Weisbeek, P.J. and Van Loon, L.C. 1998. A novel signaling pathway controlling induced systemic resistance in Arabidopsis. Plant Cell 10: 1571-1580.

Press, C.M., Wilson, M., Tuzun, S. and Kloepper, J.W. 1997. Salicylic acid produced by Serratia marcescens 91-166 is not the primary determinant of induced systemic resistance in cucumber or tobacco. Mol. Plant-Microbe Interact. 10: 761-768.

Raaijmakers, J.M. and Weller, D.M. 1998. Natural plant protection by 2,4-diacetylphloroglucinol-producing Pseudomonas spp. in take-all decline soils. Mol. Plant-Microbe Interact. 11: 144-152.

Ramachandran, S. and Sundaresan, V. 2001. Transposons as tools for functional genomics. Plant Physiol. Biochem. 39: 243-252.

Ran, L.X., Van Loon, L.C. and Bakker, P.A.H.M. 2000. No role for bacterially-produced salicylic acid in induction of systemic resistance in Arabidopsis Suppression of bacterial wilt in Eucalyptus and bacterial speck in Arabidopsis by fluorescent Pseudomonas spp. strains: conditions and mechanisms. Ph.D. Thesis L.X. Ran, Utrecht University, pp. 70-82.

Rep, M., Dekker, H.L., Vossen, J.H., de Boer, A.D., Houterman, P.M., Speijer, D., Back, J.W., de Koster, C.G. and Cornelissen, B.J.C. 2002. Mass spectrometric identification of isoforms of PR proteins in xylem sap of fungus-infected tomato. Plant Physiol. 130: 904-917.

Richardson, M., Valdes-Rodriguez, S. and Blanco-Labra, A. 1987. A possible function for thaumatin and a TMV-induced protein suggested by homology to a maize inhibitor. Nature 327: 432-434.

Ross, A.F. 1961. Systemic acquired resistance induced by localized virus infections in plants. Virology 14: 340-358.

Ruiz-Medrano, R., Jimenez-Moraila, B., Herrera-Estrella, L. and Rivera-Bustamante, R.F. 1992. Nucleotide sequence of an osmotin-like cDNA induced in tomato during viroid infection. Plant Mol. Biol. 20: 1199-1202.

Ruperti, B., Cattivelli, L., Pagni, S. and Ramina, A. 2002. Ethylene-responsive genes are differentially regulated during abscission, organ senescence and wounding in peach (Prunus persica). J. Exp. Bot. 53: 429-437.

Ryu, C.-M., Hu, C.-H., Reddy, M.S. and Kloepper, J.W. 2003. Different signaling pathways of induced resistance by rhizobacteria in Arabidopsis thaliana against two pathovars of Pseudomonas syringae. New Phytologist 160: 413-420. 
Sambrook, J., Fritsch, E.F. and Maniatis, T. 1989. Cold Spring Harbor Laboratory Press, Cold Spring Harbor, NY, USA.

Schenk, P.M., Kazan, K., Wilson, I., Anderson, J.P., Richmond, T., Somerville, S.C. and Manners, J.M. 2000. Coordinated plant defense responses in Arabidopsis revealed by microarray analysis. Proc. Natl. Acad. Sci. USA 97: 11655-11660.

Schippers, B., Bakker, A.W. and Bakker, P.A.H.M. 1987. Interactions of deleterious and beneficial rhizosphere micoorganisms and the effect of cropping practices. Annu. Rev. Phytopathol. 115: 339-358.

Singh, N.K., Bracker, C.A., Hasegawa, P.M., Handa, A.K., Buckel, S., Hermodson, M.A., Pfankoch, E., Regnier, F.E. and Bressan, R.A. 1987. Characterization of osmotin. Plant Physiol. 85: 529-536.

Singh, N.K., Nelson, D.E., Kuhn, D., Hasegawa, P.M. and Bressan, R.A. 1989. Molecular cloning of osmotin and regulation of its expression by $\mathrm{ABA}$ and adaptation to low water potential. Plant Physiol. 90: 1096-1101.

Spoel, S.H., Koornneef, A., Claessens, S.M.C., Korzelius, J.P., Van Pelt, J.A., Mueller, M.J., Buchala, A.J., Métraux, J.-P., Brown, R., Kazan, K., Van Loon, L.C., Dong, X. and Pieterse, C.M.J. 2003. NPR1 modulates cross-talk between salicylate- and jasmonate-dependent defense pathways through a novel function in the cytosol. Plant Cell 15: 760-770.

Sticher, L., Mauch-Mani, B. and Métraux, J.-P 1997. Systemic acquired resistance. Annu. Rev. Phytopathol. 35: 235-270.

Sundaresan, V., Springer, P., Volpe, T., Haward, S., Jones, J.D.G., Dean, C., Ma, H. and Martienssen, R. 1995. Patterns of gene-action in plant development revealed by enhancer trap and gene trap transposable elements. Genes Dev. 9: 1797-1810.

Tattersall, D.B., Van Heeswijck, R. and Hoj, P.B. 1997. Identification and characterization of a fruit-specific, thaumatin-like protein that accumulates at very high levels in conjunction with the onset of sugar accumulation and berry softening in grapes. Plant Physiol. 114: 759-769.

Ton, J., De Vos, M., Robben, C., Buchala, A.J., Métraux, J.-P., Van Loon, L.C. and Pieterse, C.M.J. 2002a. Characterisation of Arabidopsis enhanced disease susceptibility mutants that are affected in systemically induced resistance. Plant $\mathbf{J}$. 29: $11-21$.

Ton, J., Pieterse, C.M.J. and Van Loon, L.C. 1999. Identification of a locus in Arabidopsis controlling both the expression of rhizobacteria-mediated induced systemic resistance (ISR) and basal resistance against Pseudomonas syringae pv. tomato. Mol. Plant-Microbe Interact. 12: 911-918.

Ton, J., Van Pelt, J.A., Van Loon, L.C. and Pieterse, C.M.J. 2002b. Differential effectiveness of salicylate-dependent and jasmonate/ethylene-dependent induced resistance in Arabidopsis. Mol. Plant-Microbe Interact. 15: 27-34.

Uknes, S., Mauch-Mani, B., Moyer, M., Potter, S., Williams, S., Dincher, S., Chandler, D., Slusarenko, A., Ward, E. and Ryals, J. 1992. Acquired resistance in Arabidopsis. Plant Cell 4: $645-656$.

Van der Wel, H. and Loeve, K. 1972. Isolation and characterization of Thaumatin 1 and 2, the sweet-tasting proteins from Thaumatococcus danielii Benth. Eur. J. Biochem. 31: 221-225.

Van Loon, L.C. and Bakker, P.A.H.M. 2003. Signalling in rhizobacteria-plant interactions. In: J. E.J.W. De Kroon Visser (Ed.), Ecological Studies, Springer-Verlag, Berlin Heidelberg, pp. 287-330.

Van Loon, L.C., Bakker, P.A.H.M. and Pieterse, C.M.J. 1998. Systemic resistance induced by rhizosphere bacteria. Annu. Rev. Phytopathol. 36: 453-483.
Van Loon, L.C. and Van Strien, E.A. 1999. The families of pathogenesis-related proteins, their activities, and comparative analysis of PR-1 type proteins. Physiol. Mol. Plant Pathol. 55: 85-97.

Van Peer, R., Niemann, G.J. and Schippers, B. 1991. Induced resistance and phytoalexin accumulation in biological control of fusarium wilt of carnation by Pseudomonas sp. strain WCS417r. Phytopathology 91: 728-734.

Van Wees, S.C.M., De Swart, E.A.M., Van Pelt, J.A., Van Loon, L.C. and Pieterse, C.M.J. 2000. Enhancement of induced disease resistance by simultaneous activation of salicylate- and jasmonate-dependent defense pathways in Arabidopsis thaliana. Proc. Natl. Acad. Sci. USA 97: 87118716.

Van Wees, S.C.M., Luijendijk, M., Smoorenburg, I., Van Loon, L.C. and Pieterse, C.M.J. 1999. Rhizobacteria-mediated induced systemic resistance (ISR) in Arabidopsis is not associated with a direct effect on expression of known defense-related genes but stimulates the expression of the jasmonate-inducible gene Atvsp upon challenge. Plant Mol. Biol. 41: 537-549.

Van Wees, S.C.M., Pieterse, C.M.J., Trijssenaar, A., Van Westende, Y.A.M., Hartog, F. and Van Loon, L.C. 1997. Differential induction of systemic resistance in Arabidopsis by biocontrol bacteria. Mol. Plant-Microbe Interact. 10: 716-724.

Verhagen, B.W.M., Glazebrook, J., Zhu, T., Chang, H.-S., Van Loon, L.C. and Pieterse, C.M.J. 2004. The transcriptome of rhizobacteria-induced systemic resistance in Arabidopsis. Mol. Plant-Microbe Interact. 17: 895-908.

Vroemen, C.W., Aarts, N., In der Rieden, P.M.J., Van Kammen, A. and De Vries, S.C. 1998. Identification of genes expressed during Arabidopsis thaliana embryogenesis using enhancer trap and gene trap Ds-transposons. In: N.V. Raikhel (Ed.), Cellular Integration of Signal Transduction Pathways, Springer Verlag, Berlin, pp. 207-232.

Wang, X., Zafian, P., Choudhary, M. and Lawton, M. 1996. The PR5K receptor protein kinase from Arabidopsis thaliana is structurally related to a family of plant defense proteins. Proc. Natl. Acad. Sci. USA 93: 2598-2602.

Whalen, M.C., Innes, R.W., Bent, A.F. and Staskawicz, B.J. 1991. Identification of Pseudomonas syringae pathogens of Arabidopsis and a bacterial locus determining avirulence on both Arabidopsis and soybean. Plant Cell 3: 49-59.

Wildermuth, M.C., Dewdney, J., Wu, G. and Ausubel, F.M. 2001. Isochorismate synthase is required to synthesize salicylic acid for plant defence. Nature 414: 562-565.

Woloshuk, C.P., Meulenhoff, J.S., Sela-Buurlage, P.M., Van den Elzen, P.J.M. and Cornelissen, B.J.C. 1991. Pathogeninduced proteins with inhibitory activity towards Phytophthora infestans. Plant Cell 3: 619-628.

Yan, Z., Reddy, M.S., Ryu, C.-M., McInroy, J.A., Wilson, M. and Kloepper, J.W. 2002. Induced systemic protection against tomato late blight elicited by plant growth-promoting rhizobacteria. Phytopathol. 92: 1329-1333.

Zhang, S., Moyne, A.-L., Reddy, M.S. and Kloepper, J.W. 2002. The role of salicylic acid in induced systemic resistance elicited by plant growth-promoting rhizobacteria against blue mold of tobacco. Biol. Control 25: 288-296.

Zimmermann, P., Hirsch-Hoffmann, M., Hennig, L. and Gruissem, W. 2004. GENEVESTIGATOR. Arabidopsis microarray database and analysis toolbox. Plant Physiol. 136: $2621-2632$. 